\title{
PENDAMPINGAN KOMUNITAS PERANGKAT DESA WAREMBUNGAN MINAHASA DALAM MENGKONSERVASI HUTAN SEBAGAI UPAYA PELESTARIAN SUMBER AIR BERSIH
}

\author{
Djeli Tulandi ${ }^{1)}$, Marianus ${ }^{2)}$ \\ ${ }^{1,2)}$ Program studi pendidikan fisika, Universitas Negeri Manado Sulawesi Utara \\ E-mail: djelitulandi@unima.ac.id
}

\begin{abstract}
ABSTRAK
Kebutuhan air semakin meningkat untuk pemenuhan kebutuhan hidup manusia dan hal ini merupakan tantangan serius diantara desakan pembangunan dan industri, polusi dan perubahan iklim yang mengancam sumber daya alam. Kegiatan penyuluhan dan pendampingan kepada masyarakat menjadi salah satu alternatif dalam upaya menstimuli masyarakat Warembungan untuk melestarikan hutan dan sumber air bersih. Memberi kesadaran kepada masyarakat agar tanggap dalam menyikapi krisis air bersih di masa depan dengan tidak lagi melakukan penebangan liar, jangan membakar hutan untuk kepentingan apapun dan tidak membuka kebun di area hutan lindung. Mengajak masyarakat untuk bersama-sama melakukan penghijauan bekerja sama dengan dinas kehutanan minahasa dan mahasiswa UNIMA. Hasil angket yang dibagikan kepada responden menunjukkan bahwa pengetahuan perangkat desa dan masyarakat desa warembungan masih rendah tentang bagaimana melestarikan hutan dan air bersih. Keterlibatan dalam mengawasi dan menjaga hutan masih rendah . Hasil pertemuan dan diskusi menunjukkan adanya peningkatan pengetahuan dan kesadaran tentang pentingnya menjaga dan melestarikan hutan dan mata air yang ada di hutan Warembungan. Masyarakat dan perangkat desa bersama mahasiswa terlibat dalam penaman bibit kayu dan ada 150 bibit kayu yang di tanam.
\end{abstract}

KataKunci: Konservasi hutan, pelestarian sumber air bersih

\section{PENDAHULUAN}

Konservasi alam meliputi pemanfaatan perlindungan, pelestarian, dan terjaminnya ekosistem yang berkesinambungan. Hal tersebut karena sumberdaya alam baik flora, fauna, dan ekosistem memiliki nilai guna dan nilai ekologis, ekonomis dan sosial yang penting (Jakfar.M.2014).

Di desa Warembungan terdapat hutan yang luasnya \pm 50 ha. Kekhasan dari hutan ini adalah di tengah hutan terdapat mata air sebagai sumber air bersih bagi masyarakat Warembungan dan sekitarnya. Desa
Warembungan merupakan salah satu Desa di Kabupaten Minahasa yang mayoritas penduduknya bertani. Wilayah desa Warembungan terletak di daerah perbukitan, dan daerah perkebunan.Data profil kota Manado, 2005 menginformasikan bahwa di Desa Warembungan Minahasa terdapat mata air bersih di daerah yang namanya Bron Kumahukur dibangun oleh Belanda tahun 1922. Mata air Bron ini terletak pada ketinggian $\pm 80-100 \mathrm{~m}$ di atas permukaan laut di sebelah selatan Kota Manado. Kapasitasnya semula adalah $30 \mathrm{lt} / \mathrm{dt}$, dan saat ini menurun menjadi \pm 
8 lt/dt.Mata air Bron ini berada di daerah hutan yang luasnya \pm 50 ha. (Umagap,S dkk.2012 dan Caroline N. dkk.2013)

Mata air di Warembungan terletak di gunung sehingga memudahkan mensuplay air melalui pipa dengan sistem gravitasi Karena itu pengisian air di tong yang ada di rumah-rumah tidak menggunakan mesin pompa. Sekarang ini masyarkat di desa sekitar Warembungan mendapat pasokan air dari Lota. Air hanya disediakan di siang hari dan jika hujan airnya sedikit tercampur lumpur, dan saat tidak ada aliran listrik maka tidak ada air.

Hutan di Warembungan masih perlu diberdayakan agar menjadi hutan dengan kategori hutan produksi terbatas sehingga hutan ini tidak saja menjadi penyanggah tersedianya air tanah tapi bernilai ekonomi bagi masyarakat sekitar. Hutan yang terpelihara dengan baik akan meningkatkan manfaatnya sebagai paru-paru dunia (menyerap carbon dioksida dan penyedia Oksigen) sehingga berkontribusi bagi upaya pencegahan pemanasan global.

\section{KAJIAN LITERATUR}

Air bersih merupakan salah satu sumber daya yang sangat penting bagi kehidupan. Aktivitas manusia sangat tergantung dengan ketersediaan air bersih, mulai dari mandi, mencuci, pertanian, hingga air minum, semuabersumberdari air bersih yang dihasilkan oleh hutan.
Hutan adalah penyedia jasa lingkungan. Salah satu jasa lingkungan yang mampu diberikan oleh hutan adalah pengendalian daur air. Tidak hanya sekedar menyediakan air bersih, akan tetapi juga berperan dalam pengendalian erosi dan banjir. Daun dan ranting pohon berperan sebagai penghalau dalam proses intersepsi air hujan yang turun kebumi sehingga dapat mencegah air langsung turun ketanah.

Hutan adalah sumber kehidupan. Disadari atau tidak, diakui atau tidak, nyatanya hutan telah memberikan banyak manfaat bagi manusia, baikmereka yang tinggal di sekitarhutan, maupun yang tinggaljauhdarihutan. Bagimereka yang tinggal di sekitarhutan, hasilhasilhutansepertibuah-buahan, sayuran, sagu baruk dan lain sebagainya, bisadimanfaatkansebagaisumbermakanan.

Tidak hanya sebagai sumber makanan, akan tetapi juga sumber penghasilan. Contoh nya rotan yang bias dibentuk menjadi berbagai macam kerajinan tangan yang bias dijual.

Sebelumnya, sistem penyediaan air bersih di Kota Manado disuplay oleh mata air Bron. Paul max Mokoginta tokoh masyarakat Desa warembungan menuturkan saat ini mata air warembungan tidak dapat lagi mensuplay air ke Manado melalui pipa. Bahkan Desa Pineleng yang bertetangga dengan Warembungan juga sudah tidak kebagian air. Penyebab menurunnya debit air adalah terjadi kebakaran hutan lindung di daerah mata air bron sekitar tahun 2005, ada 
penebangan liar dan kurangnya pengawasan baik dari pemerintah maupun dari masyarakat Desa warembungan. Juga sebagian area hutan dijadikan perkebunan rakyat. Bulan september 2015 juga terjadi kebaran di area hutan Warembungan seprti gambar berikut. Sementara itu jumlah penduduk semakin meningkat sehingga kebutuhan air bersih dan kayu untuk perumahan meningkat.

\section{Cara Menjaga Kelestarian Hutan}

Hutan merupakan tanaman yang sangat familiar di muka bumi ini. Dengan adanya hutan, dapat mencegah hal-hal atau bencana yang tidak diinginkan oleh makhluk hidup, seperti longsor dan penyebab banjir. Dengan adanya hutan pula, dapat di gunakan sebagai tempat tinggal bagi makhluk hidup dan sumber daya alam yang sangat berguna. Selain itu hutan juga merupakan paru-paru dunia yang dapat menyerap karbondioksida dan menyediakan oksigen bagi kehidupan dimuka bumi ini. Hutan sendiri memiliiki beberapa macam yang ada di bumi ini. Contohnya hutan heterogen yang merupakan hutan yang terdiri ata berbagai jenis tumbuhan seperti hutan hujan tropis yang terdapat di pulau sumatera, kalimantan, sulawesi dan papua. Selain hutan heterogen adapula hutan homogen, yakni hutan yang terdiri atas satu jenis pohon saja, seperti hutan jati, hutan bambu, hutan karet, dan hutan pohon pinus.

beberapa cara melestarikan hutan :

1. Melakukan reboisasi
2. Menerapkan sistem tebang pilih

3. Menerapkan sistem tebang-tanam

4. Melakukan penebangan secara konservatif

5. Memberikan sangsi bagi penebang yang melakukan penebangan sembarangan

6. Tidak membuang sampah sembarangan di hutan

7. Melindungi dan menjaga habitat yang ada di hutan

8. Tidak mencoret-coret pohon yang ada di hutan

9. Mengurangi penggunaan kertas berlebih

10. Mengidentifikasi dan mencegah terjadinya kebakaran hutan

11. Melakukan seminar pelestarian hutan

\section{METODE PELAKSANAAN}

Tahapanyangditempuhuntukmenyelesaik anmasalahbagaimana mengkonservasi hutan dan melestarikan sumber air bersih yakni dengan metode penyuluhan dan pendampingan, melalui tahapan-tahapan seperti digambarkan dalam bagan berikut : 


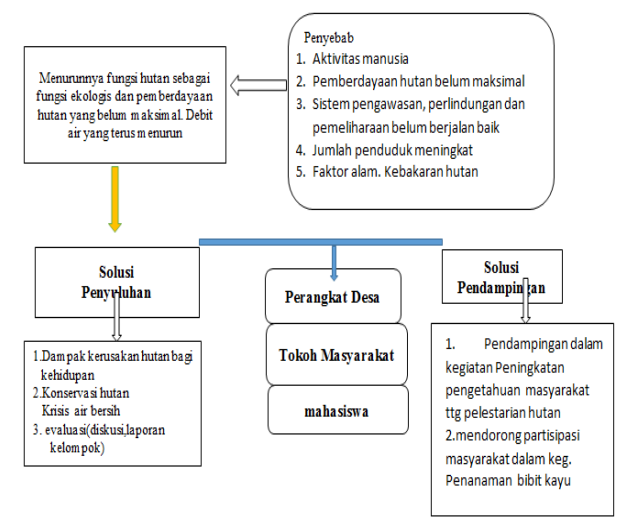

Gambar.2. Bagan Tahapan Kegiatan IbM untuk Masyarakat Umum

\section{HASIL DAN PEMBAHASAN}

\section{Profil Desa Warembungan}

Desa Warembungan terdiri dari 13 Dusun dengan jumlah penduduk sekitar 5.000 jiwa. Sebagaian besar penduduk bermata pencaharian bertani. Hukumtua Desa Warembungan bernama

Frida

TangkumahatdansekretarisDesaadalahJantje

S.Sumakul.

Para

MANTAN

HukumtuaAndriRori, BertiSumalata, Alexander Wongkardan yang sekarang Frida Tangkumahat

Luas Hutan Warembungan ada sekitar 50 ha dan dikelilingi oleh perkebunan warga. Kondisi sekarang sebelum kegiatan, pohon-pohon kayu besar sudah sangat berkurang.

\section{Pelaksanaan Kegiatan}

Kegiatan penyebaran angket ke perangkat desa Warembungan (10 orang), tokoh masyarakat Warembungan( 10) dan tokoh masyarakat desa sekitar( 5 orang). Setelah angket dianalisis, kemudian mengundang masyarkat yang mengisi angket ke pertemuan untuk mendapatkan penjelasan dan diskus materi terkait pelestarian hutan dan sumber air bersih lalu diberi tes. Selanjutnya dilakukan penanaman bibit kayu di area Hutan dengan melibatkan perangkat Desa dan Mahasiswa Fisika UNIMA. Jumlah perangkat desa dan tokoh masyarakat 25 orang.

Data Hasil kegiatan ditampilkan dalam gambar berikut:

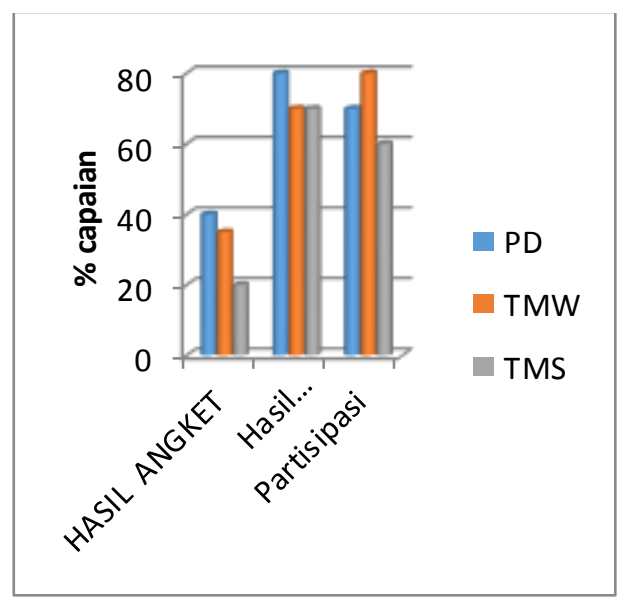

Gambar 3. \% capaian komunitas masyarakat dalam kegiatan pengabdian

Semua responden tidak dapat menjelaskan dengan benar fungsi hutan. Mereka kurang tahu bahwa fungsi hutan sebagai paruparu dunia karena Hutan dapat menghasilkan Oksegen yang dibutuhkan mahluk hidup dan menyerap $\mathrm{CO} 2$ yang berbahaya bagi kehidupandan bahwa fungsi hutan sebagai sumber ekonomi. Demikian halnya Perangkat Desa belum tahu bahwa untuk melestarikan 
hutan salah satu yang perlu dilakukan adalah sosialisasi melalui seminar, pemasangan spanduk dll. Jika hendak menebang kayu yang tidak produktif perlu dilakukan tebang tanam dan seterusnya. Demikian halnya belum semua responden menjawab dengan benar bagaimana menjaga agar debit air di mata air hutan warembungan tetap banyak/terus terpelihara. Kemudian baik masyarakat pineleng maupun masyarakat desa Warembungan belum banyak yang terlibat dalam kegiatan reboisasi. Juga belum terjalin kerjasama pemerintah terkait dengan masyarakat warembungan karena selama ini yang melakukan kegiatan reboisasi sering disponsori oleh pihak swasta seperti geraja dll.

Khususnya masyarakat pineleng yang menyatakan pelayanan air bersih kurang lancar, karena pelayanan air tergantung ada tidaknya aliran listrik. Kalau tidak ada listrik maka tidak ada air, karena air yang disuplay ke Pineleng berasal dari lotak menggunakan pompa. Juga kualitas air rendah karena jika hujan airnya kabur, dan air hanya ada pada pagi sampai jam 5 sore, jam 17.00 sampai jam 6.30 pagi air PAM tidak jalan. Padahal pada tahun-tahun sebelumnya masyarakat pineleng mendapat suplay air dari Warembungan yang airnya bersih.

Agar rersponden( perangkat desa dan masyarakat) mendapat pemahaman yang benar tentang bagaimana menjaga hutan dan melestarikan mata air yang ada di hutan
Warembungan maka setelah kami menganalisis hasil angket, kami undang dalam pertemuan untuk mendengarkan penjelasan terkait materi pelestarian hutan dan air bersih . Hasil pertemuan dan diskusi menunjukkan bahwa ada peningkatan pengetahuan dan kesadaran masyarakat bagaimana menjaga dan melestarikan hutan serta bagaimana menjadikan hutan warembungan menjadi hutan produksi terbatas dalam rangka meningkatkan ekonomi masyarakat. Terkait ekonomi masyarakat kami mendorong menjadikan Warembungan sebagai sumber air bersih, karena sekarang ini umumnya kios-kios air isi ulang yang tersebar di Kecamatan Pineleng dan Manado berasal dari mata air yang ada di hutan Desa Wembungan. Kegiatan Pengabdian ini dilanjutkan dengan penaman pohon yang melibatkan perangkat desa, masyarakat dan mahasiswa.

Penerapan pendekatan partisipatif (bukan pendekatan 'proyek') dengan 'pendampingan' ('fasilitasi') oleh LSM dan peneliti, termasuk pemberdayaan masyarakat local hendaknya terus dilakukan.(Fahmudin.A,dkk.2004).

\section{KESIMPULAN}

Berdasarkan hasil kegiatan yang telah dilakukan dapat disimpulkan bahwa :

1. Setelah diberikan materi dan diskusi informal, maka pengtahuan perangkat desa dan masyarakat desa warembungan tentang 
bagaimana menjaga dan melestarikan hutan dan mata air bersih meningkat

2. Partisipasi perangkat desa dan tokoh masyarakat mengambil bagian dalam penanaman bibit kayu meningkat.

\section{KEPUST AK AA N}

Ari.W.2010. Hutan sebagai pengatur tata air dan pencegah erosi tanah: pengelolaan dan tantangannya

Aylward, G., T. Findlay, J. Wiley. 2013. SI Chemical Data Book (4th ed.). http://en.wikipedia.org/wiki/Carbon_ dioxide. Diakses 20 Agustus 2013.

Amelia, Konservasi Wilayah Pesisir. Dikutiptanggal 14 Desember 2013

Caroline N., Tasirin, A.C., LangiM,A., Walangitan, H.D., Kalangi J.I 2013. Analisis Potensi Penyerapan Karbon Atmosferik di Stasiun Penelitian HutanBron, Desa Warembungan, Kabupaten Minahasa.

FahmuddinAgus, Meine van Noordwijk dan Subekti Rahayu.2004. Dampak Hidrologis Hutan, Agroforestri, dan Pertanian Lahan Kering sebagai Dasar Pemberian Imbalan kepada Penghasil Jasa Lingkungan di Indonesia. Proseding lokakarya di Padang. Jakfar.M.2014. Konversi alam berkelanjutan.

Journal of Tropical Forest Science 1 (3): 229243. ... Australia. Forest Trends, 2002. www.cbnrm.net/pdf/white_a_001_forestte nure.pdf .

Rahmawati.S.2004. Fungsi Dan Peranannya Bagi Masyarakat. Digitized By Usu Digital Library

Tulandi.D.2017. Buku Ajar Pengelolaan Sumber Daya Alam Dan Lingkungan. Lp2ai Unima

Umagap S, Ratag S, Walangitan, H.2012, Partisipasiperempuanpadapenerapanagrof orestri di desawarembungankecamatanpinelenghttp: //ejournal.unsrat.ac.id/index.php/cocos/arti cle/viewFile/13848/1342 